\title{
Coastal Estuaries and Lagoons: The Delicate Balance at the Edge of the Sea
}

\section{Introduction}

Coastal communities are increasingly concerned about the dynamic balance between freshwater and saltwater because of its implications for societal, economic, and ecological resources. While the mixing of freshwater and saltwater sources defines coastal estuaries and lagoons, sudden changes in this balance can have a large effect on critical ecosystems and infrastructure. Any change to the delivery of water from either source has the potential to affect the health of both humans and natural biota and also to damage coastal infrastructure. This fact sheet discusses the potential of major shifts in the dynamic freshwatersaltwater balance to alter the environment and coastal stability.

\section{Dynamic Balance}

The distributions of flora and fauna in coastal marine environments are dependent on the freshwater-saltwater balance created by the pattern of freshwater and saltwater mixing in the estuary. The location of these interfaces is important to ecosystem function, as determined by the magnitude of river flow to the coast (fig. 1).

\section{Freshwater Delivery}

Many factors influence freshwater delivery to the coast including drought, flood, groundwater seepage, precipitation, evapotranspiration, streamflow regulation, and water extraction for agriculture, industry, and public water supply. In any given location in an estuary, salinity is lower during periods of medium and high streamflow. During low streamflow and drought, saltwater intrudes into the system, and the freshwater-saltwater interface moves upstream (figs. 2 and 3).

\section{Coastal Marine Water Levels}

Marine water levels fluctuate in response to many temporal factors. Coastal water levels rise and fall daily during tides. Onshore and offshore winds can either increase or decrease tidal water levels. High tides are exacerbated during tropical cyclone events, when strong winds push higher saline water towards the shore and inundate freshwater areas with saltwater. Over longer time scales (decades to centuries), sea-level rise in combination with storm events can increase saltwater inundation in low-lying areas of estuaries and lagoons.

\section{Environmental Response and Coastal Resilience}

\section{Vegetation}

Certain vegetation zones along estuarine gradients are tolerant of a gradient of salinity, but episodes of hurricane, drought, and flood can expose ecosystems to salinity extremes that result in change to

\section{Freshwater delivery}

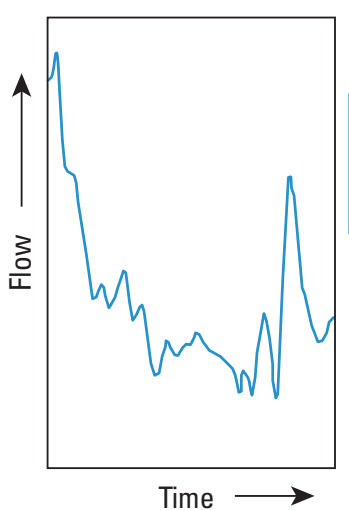

Salinity concentration, in practical salinity units (psu)

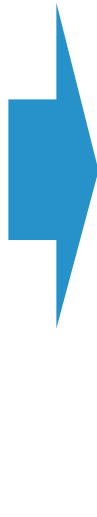

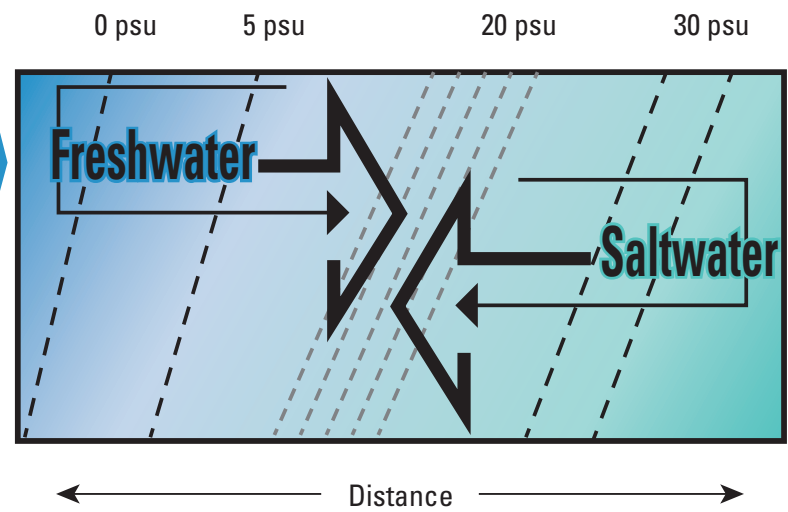

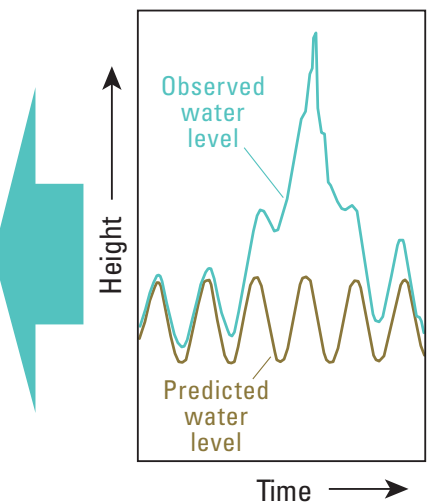

Figure 1. Salinity is balanced in coastal estuaries and lagoons by deliveries of freshwater versus saltwater. 


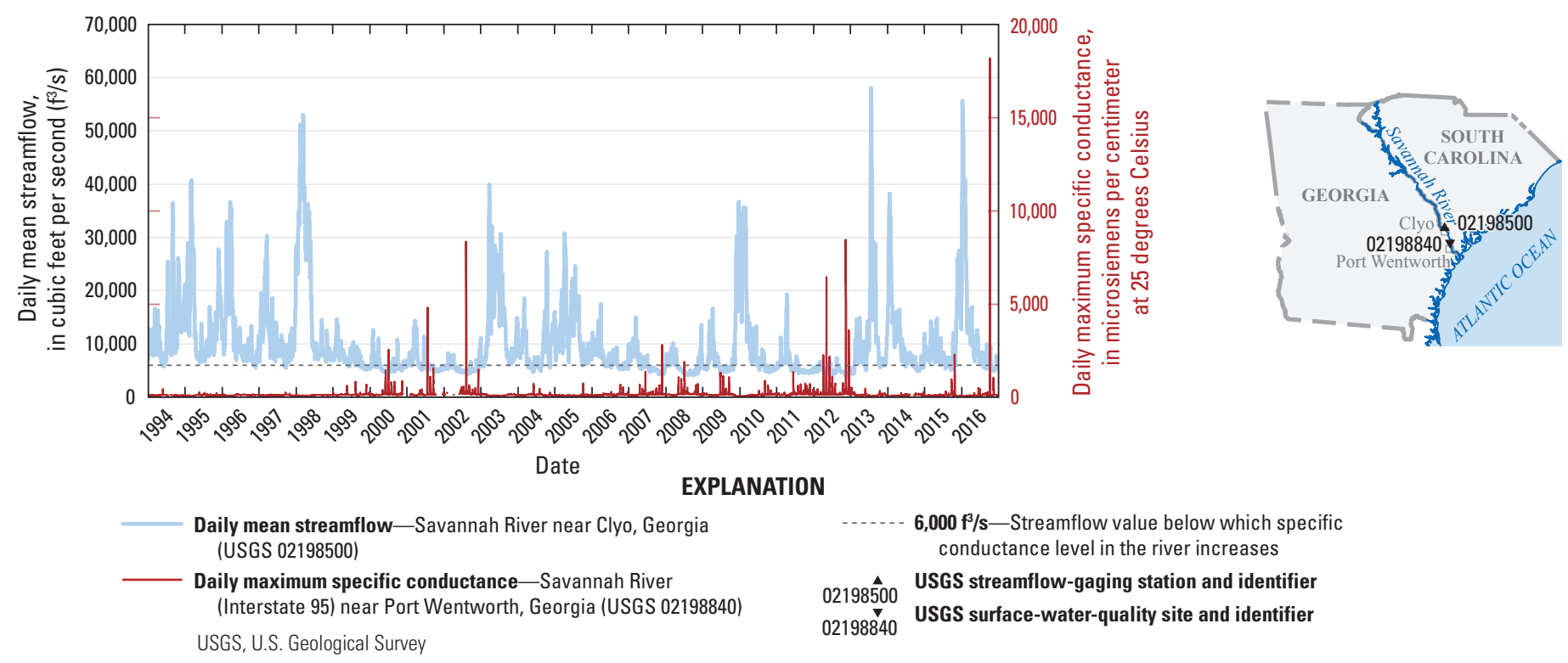

Figure 2. Relation between stream discharge and specific conductance along a portion of the Savannah River in Georgia. When freshwater discharge at Clyo is higher than 6,000 cubic feet per second in the high tides during the spring tide of the new moon, specific conductance is low at Port Wentworth (U.S. Geological Survey [USGS] gages 02198500 and 02198840, respectively; Conrads and others, 2013). Note that the data from these two nearby gages are combined because a full set of discharge and conductivity data is not available for these individual gages across the range of years (USGS, 2017).

coastal environments. If such salinity intrusion events become more frequent and intense (Knutson and others, 2010), coastal vegetation may shift dramatically in type. In particular, tidal freshwater communities may shift to more salt-tolerant types of vegetation or to open water.

Although vegetation can be resilient to short-term salinity changes, zones related to salinity tolerance may move landward if the salinity limitations of species are exceeded over long periods of time (fig. 3). In other cases, coastal wetlands may transition overall to a more salt-tolerant species, or they may die off (fig. 4). As an example of vegetation transition in an estuary, in the Mississippi River Delta, a multiyear drought with higher levels of salinity caused a freshwater marsh to transition to an intermediate marsh.

\section{Fisheries}

For fisheries, increases in freshwater flow can have either positive or negative effects. For example, annual Callinectes sapidus (blue crab) landings are correlated with the freshwatersaltwater balance created by freshwater delivery to the southeastern coast of the United States (Childress, 2012). As salinity increases during periods of coastal drought, blue crabs move farther upstream, decreasing predation by alligators but increasing crab exposure to lethal parasites. Other examples of animal movement in response to salinity changes in estuaries are common. In the Suwannee River, an increase in freshwater flow increased critical habitat for juvenile Acipenser oxyrinchus (Gulf sturgeon) (Randall and Sulak, 2007), whereas a decrease in freshwater due to drought reduced oyster production in Apalachicola Bay, Florida (Havens and others, 2013).

\section{Coastal Vulnerabilities}

Human infrastructure along the coasts, such as infrastructure related to freshwater supply and protection for human needs, storm protection, navigation, and tourism and recreation, is also vulnerable to salinity changes.

\section{Freshwater Supply and Protection}

Many municipal water-supply systems along the southeastern coast of the United States are vulnerable to saltwater intrusion and climate change (Furlow and others, 2002). Often, municipal water intakes are near the freshwatersaltwater interface of tidal rivers, so salinity intrusion events can threaten freshwater sources for humans. To effectively manage water supply, water-resource managers need estimates of potential changes in the future frequency, duration, and magnitude of salinity intrusion events near water-supply intakes, especially in view of potential sea-level rise induced by climate change or increase in upstream freshwater extraction. Critical sources of drinking water from groundwater can also be affected (Prinos and others, 2014).

Alteration of salinity regimes in coastal water bodies can influence the health of humans and estuarine species in subtle ways. Changes to the water and sediment quality can alter species of algae, particularly if the environment is becoming more saline. While many types of algae have no influence on human or animal well-being, some types of algae produce toxins. During toxic algal blooms, toxins reach hazardous levels with prolonged and negative effects on estuaries, creating

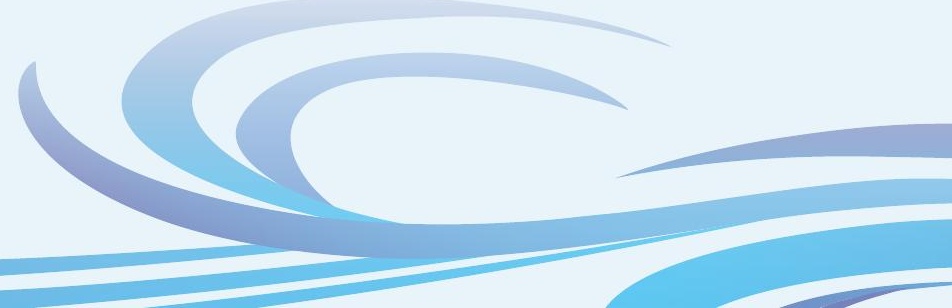




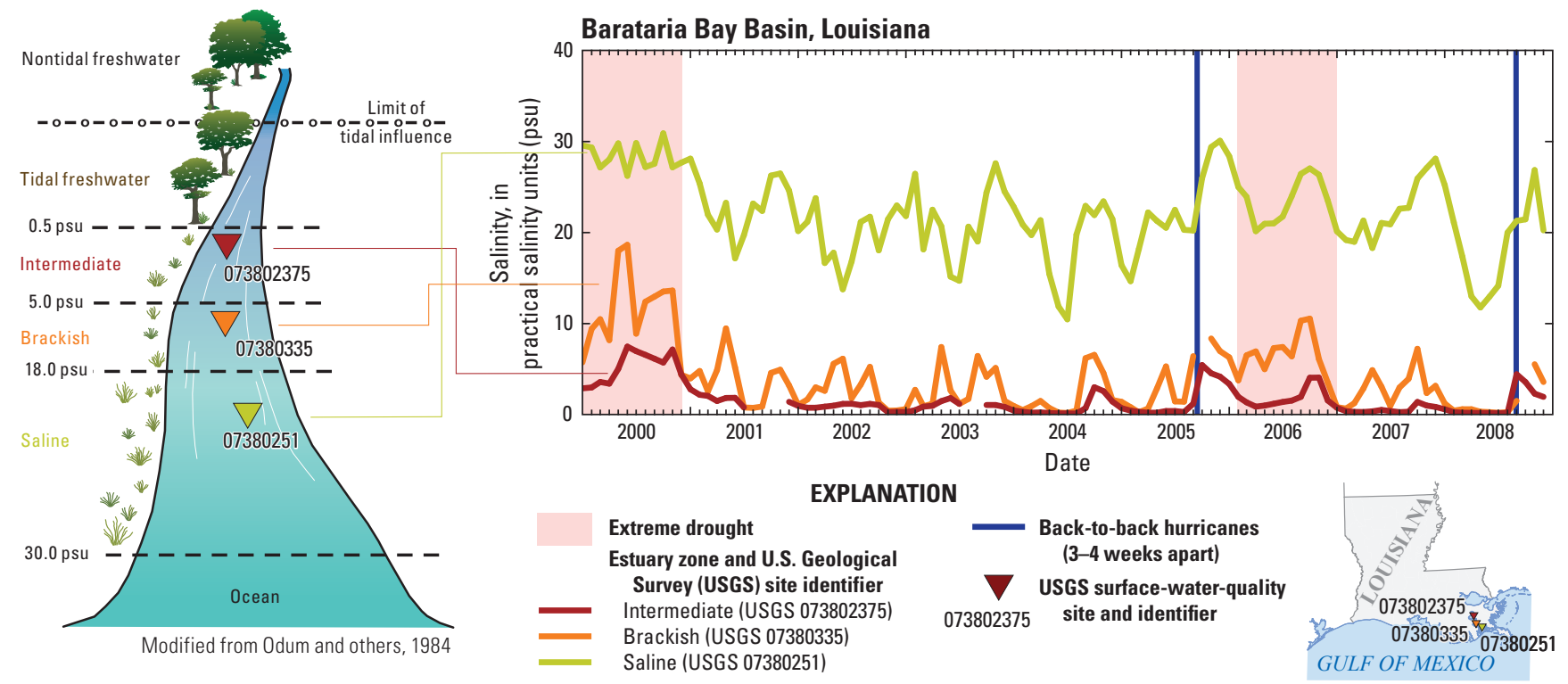

Figure 3. Monthly salinity concentrations in intermediate, brackish, and saline waters in Barataria Bay Basin, Louisiana, 2000-2008, and estuarine response to normal conditions and extreme weather events. Vegetation responds by moving landward or seaward as related to the salinity tolerance of species.

conditions of low oxygen, fish kills, and shellfish poisoning in humans. Toxic algal blooms also reduce recreational opportunities. Similarly, harmful metals such as mercury, arsenic, and lead increase in availability when salinity levels are low. Harmful metals in clay soils can accumulate along widened, slow-moving channels or where salinity increases slightly. In some cases, however, as salinity increases, metals detach from clayey sediments or transform into more toxic species (for example, methylmercury). Such metals can enter the food chain and accumulate in fish and other organisms in a process called bioaccumulation. This contamination of the food chain can be dangerous if contaminated fish are consumed by humans. An understanding of the routes of entry of heavy metals into the food chain is important to managers for developing management strategies to reduce heavy metal contamination of ecosystems.

Salinity intrusion can cause many public safety and national security issues, especially near critical infrastructure such as municipal and industrial water intakes and military facilities. In such cases, freshwater supply for coastal communities can dwindle quickly and become a public safety issue if alternative freshwater resources are not available. Many industrial intakes in tidal freshwater zones have a very low threshold for salinity because of the corrosive potential of seawater on industrial machinery, particularly boilers. The operations of many facilities related to military bases and nuclear power can be disrupted by salinity intrusion for the same reason.
Figure 4. Ghost forests caused by rising salinity levels on the U.S. Gulf Coast. 


\section{Coastal Protection From Flooding and Storms}

Coastal vegetation forms a natural defense against flooding for coastal communities during storms by reducing destructive wave energy. In the United States, wetlands provide about $\$ 23$ billion annually in storm-surge protection services (Costanza and others, 2008). If vegetation is damaged, its ability to protect coasts from storms can be impaired (Costanza and others, 2008).

\section{Navigation}

Modifications to port facilities in estuaries can have a substantial effect on the location of the freshwater-saltwater interface. In particular, the deepening of shipping channels to accommodate deeper draft cargo ships can shift the interface farther upstream. These modifications can expose water intakes to salinity and exacerbate other problems related to any increases in the frequency, magnitude, and duration of salinity intrusion events.

\section{Tourism and Recreation}

Recreation is an important part of the U.S. economy (Colgan, 2004). Estuaries are important areas for activities such as hiking, fishing, bird watching, canoeing, and hunting. Although estuarine regions encompass only 12.6 percent of the continental United States, these regions compose 49 percent of the economic output of the United States (Pendleton, 2011). As an example of the importance of recreation to the economy, in 2011, more than 46 million recreational fishermen generated over $\$ 48$ billion in retail sales in the United States (Southwick Associates, 2013). Rises in tourism and recreation illustrate the importance of maintaining estuarine health for the prosperity of coastal communities.

\section{USGS Capabilities}

The U.S. Geological Survey (USGS) provides a wide variety of products designed to aid decision makers in their understanding of salinity dynamics and other factors that affect critical coastal habitats. These products include hydrologic monitoring data, biological data, reports of scientific investigations, data releases, scientific support, and data visualization and analysis tools for coastal estuaries and lagoons.

For more information, visit www.usgs.gov.

\section{References}

Childress, M., 2012, Status of blue crabs in South Carolina. State of Basin Rep. 2: Clemson. S.C., Clemson University, Newsletter.

Colgan, C.S., 2004, Employment and wages for the U.S. ocean and coastal economy: Monthly Labor Review, v. 127, no. 11, p. 24-30.

Conrads, P.A., Roehl, E.A., Jr., Daamen, R.C., and Cook, J.B., 2013, Simulation of salinity intrusion along the Georgia and South Carolina coasts using climate-change scenarios: U.S. Geological Survey Scientific Investigations Report 2013-5036, 92 p. and 5 apps., http://pubs.usgs.gov/sir/2013/5036/.
Costanza, R., Perez-Maqueo, O., Martinez, M.L., Sutton, P., Anderson, S., and Mulder, K., 2008, The value of coastal wetlands for hurricane protection: AMBIO, v. 37, p. 241-248.

Furlow, John, Scheraga, J.D., Freed, Randal, and Rock, Ken, 2002, The vulnerability of public water systems to sea level rise, in Lesnik, J.R., ed., Proceedings of the Coastal Water Resource Conference: Middleburg, Va., American Water Resources Association, TPS-02-1, p. 31-36.

Havens, K., Allen, M., Camp, E., Irani, T., Lindsey, A., Morris, J.G., Kane, A., Kimbro, D., Otwell, S., Pine, B., and Walters, C., 2013, Apalachicola Bay oyster situation report: Gainesville, Fla., University of Florida Sea Grant, Technical Publication 200, 32 p., accessed August 8, 2017, at http:// www.flseagrant.org/wp-content/uploads/tp200_apalachicola oyster_situation_report.pdf

Knutson, T.R., McBride, J.L., Chan, J., Emanuel, K., Holland, G., Landsea, C., Held, I., Kossin, J.P., Srivastava, A.K., and Sugi, Masato, 2010, Tropical cyclones and climate change: Nature Geoscience, v. 3, p. 157-163.

Odum, H.T., 1984, Energy analysis evaluation of coastal alternatives: Water Science Technology, v. 16, p. 717-734.

Pendleton, L.H., 2011, The economic and market value of coasts and estuaries: What's at stake?: Arlington, Va., Restore America's Estuaries, 175 p.

Prinos, S.T., Wacker, M.A., Cunningham, K.J., and Fitterman, D.V., 2014, Origins and delineation of saltwater intrusion in the Biscayne aquifer and changes in the distribution of saltwater in MiamiDade County, Florida: U.S. Geological Survey Scientific Investigations Report 2014-5025, $101 \mathrm{p}$.

Randall, M.T., and Sulak K.J., 2007, Relationship between recruitment of Gulf sturgeon and water flow in the Suwannee River, Florida: American Fisheries Society Symposium, v. 56, p. 69-83.

Southwick Associates, 2013, Sportfishing in America: An economic force for conservation: American Sportfishing Association, $12 \mathrm{p}$.

U.S. Geological Survey, 2017, National Water Information System: Mapper: Accessed November 29, 2017, at https:// maps.waterdata.usgs.gov/mapper/index.html.

By Paul A. Conrads (deceased), Kirk D. Rodgers, Davina L. Passeri, Scott T. Prinos, Christopher Smith, Christopher M. Swarzenski, and Beth A. Middleton 